\title{
DOPPLER DETERMINED BLOOD PRESSURE RECORDINGS: THE EFFECT OF VARYING CUFF SIZES IN CHILDREN
}

\author{
Gary E. Hitl and Richard H. Machin
}

SINCE HERISSON'S FIRST INVENTION of a method of indirect measurement of blood pressure, ${ }^{1}$ blood pressure determinations have become standard practice in clinical anaesthesia. Blood pressure determinations under certain circumstances (newborn and premature infant, ${ }^{2}$ cardiopulmonary bypass, ${ }^{3}$ obesity and in patients with peripheral vasoconstriction ${ }^{4}$ ) may be extremely difficult if not impossible by the auscultation or palpation methods.

Ware ${ }^{5}$ in 1965 suggested the motion of a pulsating artery partially compressed by a blood pressure cuff could be detected by the Doppler ultrasonic technique for estimation of arterial blood pressure. Since that time the Doppler ultrasonic technique has been shown to be closely correlated with direct intra-arterial blood pressure recordings and to auscultatory determination. ${ }^{6}$ Arterial pressures as low as 40 torr have been accurately recorded with the Doppler technique. ${ }^{11}$ Because of this close correlation, the Doppler has become commonly used during routine anaesthesia, ${ }^{4}$ cardiopulmonary bypass, ${ }^{3}$ closed cardiac surgery in neonates and in critical care nurseries. ${ }^{7}$ The Doppler is useful for other purposes, as the diagnosis of air embolism during neurosurgical procedures in the sitting position, ${ }^{8}$ and air emboli during cardiopulmonary bypass, the efficiency of cardiac massage, ${ }^{3}$ evaluation of occlusive peripheral vascular disease, traumatic vascular injury, arrhythmias, detection of foetal heart tones, ${ }^{4}$ and many others. The Doppler may obviate invasive techniques (i.e. arterial cannulization) that may have complications. ${ }^{4}$

The importance of correct cuff size has been well documented by Woodbury, Robinow and Hamilton (1938). Later Long, et al. ${ }^{9}$ again showed that too narrow a cuff and too short a cuff bladder will cause artificially high blood pressure readings while too large a cuff can cause falsely low blood pressure readings. Therefore, this study was undertaken to determine the effect of too large a cuff, the correct size cuff and too small a cuff on systolic blood pressures determined by the Doppler ultrasonic technique.

\section{METHODS}

Ten children between the ages of 12 months and 14 years were selected at random and the length of their upper arms were measured (acromion process to olecranon ). A blood pressure cuff approximately two-thirds this distance in width was selected to represent the "correct" size cuff and two other cuffs, and 15-20 per cent larger and one 15-20 per cent smaller were chosen.

Blood pressures were then measured by the standard auscultatory method with

From the Department of Anesthesiology, The University of Utah College of Medicine, 50 North Medical Drive, Salt Lake City, Utah, 84132. 
TABLE I

\begin{tabular}{|c|c|c|c|c|}
\hline \multirow[b]{2}{*}{ Patient } & & \multicolumn{3}{|c|}{ Cuff Size } \\
\hline & & Small & Correct & Large \\
\hline $\begin{array}{l}3 \text { years old } \\
\text { Male } \\
19.5 \mathrm{lb} .\end{array}$ & $\begin{array}{l}A \\
D\end{array}$ & $\begin{array}{l}100 \\
100\end{array}$ & $\begin{array}{l}80 \\
85\end{array}$ & $\begin{array}{l}85 \\
80\end{array}$ \\
\hline $\begin{array}{l}4 \text { years old } \\
\text { Male } \\
25 \mathrm{lb} .\end{array}$ & $\begin{array}{l}\mathrm{A} \\
\mathrm{D}\end{array}$ & $\begin{array}{l}120 \\
130\end{array}$ & $\begin{array}{r}95 \\
100\end{array}$ & $\begin{array}{r}100 \\
95\end{array}$ \\
\hline $\begin{array}{l}1 \text { year old } \\
\text { Male } \\
23 \mathrm{lb} .\end{array}$ & $\begin{array}{l}A \\
D\end{array}$ & $\begin{array}{l}130 \\
135\end{array}$ & $\begin{array}{l}110 \\
105\end{array}$ & $\begin{array}{l}90 \\
90\end{array}$ \\
\hline $\begin{array}{l}2 \text { years old } \\
\text { Male } \\
25 \mathrm{lb} .\end{array}$ & $\begin{array}{l}\mathrm{A} \\
\mathrm{D}\end{array}$ & $\begin{array}{l}155 \\
160\end{array}$ & $\begin{array}{l}150 \\
150\end{array}$ & $\begin{array}{l}135 \\
145\end{array}$ \\
\hline $\begin{array}{l}13 \text { years old } \\
\text { Male } \\
97 \mathrm{lb} \text {. }\end{array}$ & $\begin{array}{l}A \\
D\end{array}$ & $\begin{array}{l}120 \\
115\end{array}$ & $\begin{array}{l}105 \\
105\end{array}$ & $\begin{array}{r}100 \\
95\end{array}$ \\
\hline $\begin{array}{l}2 \text { years old } \\
\text { Male } \\
31 \mathrm{lb} .\end{array}$ & $\begin{array}{l}\mathrm{A} \\
\mathrm{D}\end{array}$ & $\begin{array}{l}150 \\
150\end{array}$ & $\begin{array}{l}130 \\
130\end{array}$ & $\begin{array}{l}130 \\
130\end{array}$ \\
\hline $\begin{array}{l}13 \text { months old } \\
\text { Male } \\
19 \mathrm{lb} \text {. }\end{array}$ & $\begin{array}{l}\mathrm{A} \\
\mathrm{D}\end{array}$ & $\begin{array}{l}150 \\
150\end{array}$ & $\begin{array}{l}120 \\
125\end{array}$ & $\begin{array}{l}110 \\
110\end{array}$ \\
\hline $\begin{array}{l}2 \text { years old } \\
\text { Female } \\
22 \text { lb. }\end{array}$ & $\begin{array}{l}\mathrm{A} \\
\mathrm{D}\end{array}$ & $\begin{array}{l}160 \\
160\end{array}$ & $\begin{array}{l}140 \\
140\end{array}$ & $\begin{array}{l}140 \\
135\end{array}$ \\
\hline $\begin{array}{l}1 \text { year old } \\
\text { Male } \\
18 \mathrm{lb} .\end{array}$ & $\begin{array}{l}\mathrm{A} \\
\mathrm{D}\end{array}$ & $\begin{array}{l}135 \\
145\end{array}$ & $\begin{array}{l}140 \\
130\end{array}$ & $\begin{array}{l}130 \\
130\end{array}$ \\
\hline $\begin{array}{l}14 \text { years old } \\
\text { Female } \\
105 \mathrm{lb} \text {. }\end{array}$ & $\begin{array}{l}\mathrm{A} \\
\mathrm{D}\end{array}$ & $\begin{array}{l}170 \\
165\end{array}$ & $\begin{array}{l}150 \\
150\end{array}$ & $\begin{array}{l}135 \\
130\end{array}$ \\
\hline \multicolumn{5}{|c|}{$\begin{array}{c}\mathrm{A}=\text { Auscultatory Systolic Pressure. } \mathrm{D}=\text { Doppler Systolic Pressure. } \\
\text { Mean Values T values }\end{array}$} \\
\hline $\begin{array}{l}\text { Doppler } \\
\text { Pressures }\end{array}$ & $\begin{array}{l}\text { Small Cuff } \\
\text { Correct Cuft } \\
\text { (Control) } \\
\text { Large Cuff }\end{array}$ & $\begin{array}{l}141 \text { torr } \\
122 \text { torr } \\
114 \text { torr }\end{array}$ & $\begin{array}{l}-8.14 \\
0 \\
3.75\end{array}$ & $\mathrm{P}<0.001$ \\
\hline
\end{tabular}

each size cuff and the average of five readings recorded. The readings were repeated with the Doppler flow meter Model 803 (Parks Electronics Laboratory, Beaverton, Oregon) with attached earphones. Two different observers took and recorded each pressure. The results were then averaged and analyzed by Students t-test. The results were highly significant and are shown in Table I.

\section{Discussion}

As can be seen from the data, cuff size is a determining factor in blood pressure recording with the Doppler ultrasonic technique. A small cuff will produce an artificially elevated blood pressure while too large a cuff will produce a falsely 
low recording. Therefore, the selection of proper cuff size is as important using the Doppler technique as with the auscultatory method in the paediatric patient.

The physical properties of ultrasound have been described elsewhere. Briefly, an ultrasound oscillator and transducer which transmits and receives the generated ultrasound is the basic structure of the Doppler apparatus. The transducer contains two chips of lead zercinate titanate crystals; one chip emits ultrasound, the other receives. If the ultrasound strikes an immobile structure such as the compressed arterial wall, the ultrasound frequency is reflected back unchanged. If a moving structure (pulsating artery) is encountered, however, the frequency is altered up or down (Doppler effect) and this is detectable by an audible alteration of the reflected sound. The first motion of the arterial wall occurs as cuff pressure is lowered to systolic pressure, allowing opening of the artery under high velocity and causing an increase in frequency of the reflected ultrasound. This is detected as an audible alteration of the amplified sound. When cuff pressure falls just below intra-arterial pressure (diastolic pressure), the artery remains open (motionless) resulting in a distant muffling of the ultrasound signal. ${ }^{7}$ If no structure is encountered which is moving faster than $0.5 \mathrm{~cm} / \mathrm{sec}$, no signal will be heard. ${ }^{10}$

In summary, the Doppler ultrasound technique is invaluable in determination of arterial blood pressure as described above. Cuff size has been shown to be equally important in systolic pressure recordings with the Doppler ultrasound as it is in the auscultatory method; that is, too small a cuff causing artificially elevated pressure recordings and too large a cuff causing artificially too low a recording, though not as marked as too small a cuff.

\section{SUMMARY}

Ten children ages 12 months to 14 years were studied to determine the effect of cuff size on blood pressure determined by the Doppler ultrasonic technique compared to blood pressure recordings by the auscultatory method. It was found that Doppler determined blood pressure varied with cuff size as it does with the auscultatory method. Too small a cuff will give an artificially high recording while too large a cuff causes too low a recording. The effect of the large cuff is less marked than the effect of too small a cuff.

\section{RÉSUMÉ}

Les chiffres de pression artérielle obtenus par méthode auscultatoire et par usage d'un appareil ultrasonique Doppler ont été comparés chez 10 enfants de 12 à 14 ans et ce avec des manchettes de largeur différente. Chez tous les enfants, deux observateurs ont fait cinq lectures avec les deux méthodes et avec une manchette large des deux tiers de leur distance acromio-olécrânienne, puis avec une manchette de 15 à 20 pour cent plus étroite et, enfin, avec une manchette de 15 à 20 pour cent plus large.

Tel que prévu, les mêmes effets décrits avec la méthode auscultatoire ont été retrouvés avec l'usage du Doppler, une manchette trop étroite donnant des lectures plus hautes que la réalité et une manchette trop large donnant des valeurs trop 
basses, les variations étant cependant moins grandes que celles observées avec la manchette trop étroite.

\section{REFERENCES}

1. Collins, V.J. Principles of anesthesiology. Lea and Febiger, pp. 46-52 (1972).

2. McLaughlin, G.W., et al. Indirect measurement of blood pressure in infants utilizing Doppler ultrasound. J. of Pediat. 79: 300 (1971).

3. Waltemath, C.L. \& Pheuss, D.D. The determination of blood pressure in low flow states by the Doppler technique. Anesthesiology 34: 77-79 (1971).

4. Lowny, R.L., et al. The Doppler: An aid in monitoring blood pressure during anesthesia. Anesth. \& Analg. 52: 531-535 (1973).

5. WARE, R.W. New approaches to the indirect measurement of human blood pressure. Proc. 3rd Nat. Biomed. So. Instrumentation Symposium (ISA BM-65) (1965).

6. Hernandez, A., et al. Measurement of blood pressure in infants and children by the Doppler ultrasound technique. Pediatrics 48: 788-794 (1971).

7. Gordon, L.S., et al. Systolic and diastolic blood pressure measurements by transcutaneous Doppler ultrasound in premature infants in critical care nurseries and at closed heart surgery. Anesth. \& Analg. 53: 914-918 (1974).

8. Maroon, J.S. \& Albin, M.S. Air embolism diagnosed by Doppler ultrasound. Anesth. \& Analg. 53: 399-402 (1974).

9. Long, M., Dunlop, J., et al. Blood pressure recording in children. Archives of Disease in Children 46: 636-640 (1971).

10. STEGALl, H.F., et al. Indirect measurement of arterial blood pressure by Doppler ultrasonic sphygmomanometry. J. of Applied Physiology 25: 793-798 (1968).

11. KinBy, R.R., et al. Transcutaneous Doppler measurement of blood pressure. Anesthesiology 31: 86-89 (1969). 